\title{
Resources, violence and the telluric geographies of small wars
}

Korf, Benedikt

\begin{abstract}
A growing literature debates the proposition that insurgency in 'small wars' is primarily driven by opportunities to exploit or loot abundant natural resource and by feasibility factors. While recent studies on the geography of opportunity, feasibility and predation have qualified some of these broad claims, the literature is still in need of a better understanding of the micro-geographies of small wars. Through a critical discussion of this literature, I will argue for an analytics of 'telluric geographies' that studies the geography of rule, violence and affect in small wars.
\end{abstract}

DOI: https://doi.org/10.1177/0309132510394120

Posted at the Zurich Open Repository and Archive, University of Zurich

ZORA URL: https://doi.org/10.5167/uzh-52740

Journal Article

Accepted Version

Originally published at:

Korf, Benedikt (2011). Resources, violence and the telluric geographies of small wars. Progress in Human Geography, 35(6):733-756.

DOI: https://doi.org/10.1177/0309132510394120 


\section{Resources, Violence and the Telluric Geographies}

\section{of Small Wars}

Benedikt Korf

Department of Geography, University of Zurich, Winterthurerstrasse 190, CH 8057

Zurich. E-mail: benedikt.korf@geo.uzh.ch

Forthcoming in: Progress in Human Geography

Update: 10nov2010

\section{Acknowledgements:}

I would like to thank Roland Bleiker, Christine Bichsel, Tilman Brück, Sarah Byrne,

Tobias Hagmann, Stathis Kalyvas, Timothy Raeymaekers and Conrad Schetter as

well as several anonymous referees and the editors of Progress for very useful, critical, while encouraging comments on several drafts of this paper. All errors remain my sole responsibility. 


\title{
Resources, Violence and the Telluric Geographies of Small Wars
}

\begin{abstract}
A growing literature debates the proposition that insurgency in "small wars" is primarily driven by opportunities to exploit or loot abundant natural resource and by feasibility factors. While recent studies on the geography of opportunity, feasibility and predation have qualified some of these broad claims, the literature is still in need of a better understanding of the micro-geographies of small wars. Through a critical discussion of this literature, I will argue for an analytics of "telluric geographies" that studies the geography of rule, violence and affect in small wars.
\end{abstract}

\section{Introduction:}

In Theorie des Partisanen Carl Schmitt writes that a partisan is connected "... with the soil, with the autochthonous population and the geographical characteristics of the country - the mountain, forest, jungle, and desert [...]. The partisan is distinguished from the pirate as well as from the corsair ..." (Schmitt [1963] 2006, 26-27; translation from original). ${ }^{1}$ Schmitt's romantic image of the partisan as a "telluric" insurgent seems but a distant murmur in comparison to characterizations of the modern insurgent: Paul Collier describes insurgency as "quasi-criminal activity" - an instrumental strategy to monopolize economic rents (Collier 2000). Georg Elwert

\footnotetext{
1 I thank Conrad Schetter for directing me to this quote and to the "telluric" character of the partisan figure in Carl Schmitt's thought, see also, Meyer et al. (2010). The term "telluric" emphasizes the territorialized, earth-bound mode of operation of the partisan, who is connected to the "soil" and to the population, in Schmitt's view. I will come back to this image of "telluric" at the end of the paper when I summarize my critique of the literature reviewed in this paper. "Telluric" also reminds me of the Schiller's saga of Wilhelm Tell, where Tell and his allies are bound together by their attachment to their territory. Of course, one should not read into the term "telluric" an apology of a Ratzelian kind of environmental determinism.
} 
writes that insurgents turned warlords "are ... entrepreneurs who use deliberate violence as an efficient tool for achieving economic gains" (Elwert 1999, 87). Collier, Elwert - and after them many other writers - maintain, contra Schmitt, that the modern insurgent is not distinguishable from a pirate or a bandit. When insurgency occurs today, these authors suggest, it is because it is economically rational to do so. Is war, to re-paraphrase Clausewitz, the continuation of economics by other means? ${ }^{2}$ Paul Collier' proposition that the opportunity to loot or exploit resources was crucial for the feasibility of violent rebellion to emerge and to be sustained (his "greed" theory") stimulated a large body of literature that writes about "greed", "opportunity to loot", "resource curse", "resource wars" largely relating to "intrastate" or "civil" wars (Collier 2000, Collier and Hoeffler 2004, 2005, Collier et al 2004, Collier et al 2009). Most writings in this tradition or "paradigm" (Ron 2005) tend to concur with the view that an abundance of natural resources can provide opportunities for violence, but different types of explanatory models are employed to explicate the causal links between resource abundance and the occurrence or persistence of such violence, warfare and insurgency.

Although this research field (“ethnicity, natural resources and violent civil conduct") has been identified by the Times Higher Education in 2009 as one of the top 10 research fronts in the social sciences (Wrigley and Overman 2010, 5, Table 4), it has remained a rather marginal field within the study of the geographies of war and peace. ${ }^{3}$ John O'Loughlin (2005) reminds us that these types of war have often occurred in a "hegemonic shadow" and scholarly attention among geographers has

\footnotetext{
${ }^{2}$ Clausewitz made the famous claim that war was the continuation of politics by other means. David Keen first re-phrased this into "economics by other means" (Keen 1997, 2000).

${ }^{3}$ For a recent review of the variety of geographical literature in this field see: Kobayashi (2009) and the contribution in the special issue of the Annals of the Association of American Geographers 99 (5). In Colin Flint's edited volume on The geography of war and peace (2005), only few contributions engage explicitly with this debate, e.g. Le Billon (2005b) and, to some extent, O'Loughlin (2005).
} 
mainly focused on the "hot wars" (Flint 2005, 3) that occurred after 9/11. Only more recently have some contributions started to attend to the geography of "resource violence" - to the spatialities and temporalities of resource exploitation and their entanglements with violent conflict. Though they have been important and influential (beyond geography as a discipline), these conceptualizations are often still in an early stage of development (e.g. Le Billon 2001, Le Billon 2008, O’Loughlin and Raleigh 2007, Raleigh et al. forthcoming).

This paper discusses this emergent research field that explores the geography of opportunity and feasibility of violent insurgency and its link to natural resource exploitation, looting and predation. This literature has been important to specify and qualify some of the rather broad claims made by Collier's original propositions and the research field that emerged as a response to his studies (Ron 2005). This geography of opportunity, feasibility and predation literature has helped to clarify some of the conceptual micro-foundations of a research field that has predominantly relied on large-N (cross-country) statistical analysis at the cost of leaving the conceptual micro-foundations that specify causal mechanisms to link measurement and interpretation underspecified (Cramer 2002, Kalyvas 2006, 2008, Korf 2006, Verwimp et al. 2009). It is on these specifications of micro-foundations (Kalyvas 2008), not on statistical correlation mechanisms that this review is focused. This paper is an attempt to review these explicit and implicit micro-foundations and to point to some blind spots pertinent in the literature.

The "geography of opportunity, feasibility and predation" literature reviewed in this paper has (a) introduced terrain and location factors in shaping opportunity and feasibility of violent insurgency, (b) linked resource typologies with propensities of violent insurgency, and (c) identified transnational resource flows as spaces of 
opportunity for multiple actor types. It has done so by utilizing spatially explicit methodologies, by conceptual innovations and by new empirical studies using a finer geographical scale. While this literature has helped refine understanding of the geography of opportunity, feasibility and predation, it has mainly worked through the conceptual lenses provided by Collier's opportunity and feasibility concepts. This reliance on Collier comes at a cost. Studying the "geography of opportunity, feasibility and predation" focuses on belligerents' motivations, strategies and opportunities and blinds the analyst to the complex "struggles over geography" (Said 1993, Watts 2000) - or, what I will call the "telluric geographies" of such wars. These "telluric geographies" entail a much more complex geography of actors, strategies, motivations and opportunities; it entails more than rational action and strategizing, it entails more than simply the opportunity for combat and personal enrichment.

After reviewing the "micro-foundations" of Collier's opportunity and feasibility concepts, I will develop a typology to categorize the approaches in the literature on the geography of opportunity, feasibility and predation. While these important contributions will be acknowledged, I will argue that the micro-foundations of this literature have blind spots. I will therefore propose an alternative research agenda on the geography of rule, violence and affect, which I call "telluric geographies." This agenda deepens and broadens the "micro-foundations" of the study of small wars, in particular by exploring the entanglements of greed and grievance. In sketching this agenda, I first discuss the work of two authors - Stathis Kalyvas and Michael Watts - who, while coming from very different traditions - have both provided a more nuanced analytics of the geography of violence and coercion. Second, I discuss two research fields that require more attention, i.e. the subaltern 
geographies and agencies in the political economy of small wars and the affective dynamics of violence in warfare.

\section{$\underline{\text { Small wars }}$}

The controversy about greed-driven wars, the "resource curse" and "resource wars" is closely related to the "new wars" debate, though the two are not identical. In New and Old Wars (1999), Mary Kaldor defined violence against non-combatants, and the deliberate targeting of non-combatants, as an essential component of these "new" wars. Along with other authors (e.g. Münkler 2002), Kaldor thereby identified crime as "the raison d'être of the new wars" (Gregory 2010, 167). Rebellion had become a private good (with the objective of personal enrichment) rather than a public good (with the objective of political liberation). This resonated well with Paul Collier's proposition that opportunity to loot or exploit resources was the best explanatory variable to explain the onset of such wars (Collier and Hoeffler 2004).

Mbembe $(2001,78)$ describes this as privatization of the means of coercion. The validity of this criminalization proposition and the distinction between "old" (politically noble) versus "new" (economically driven) small wars has remained disputed, though (Gregory 2010, Kalyvas 2001). Some of the criticisms are that firstly, it is not at all clear that violence against civilians has increased compared to earlier warfare. Secondly, elements of crime have been present in various types of warfare throughout history. Thirdly, it is difficult to develop one general theory of "new wars" as these entail a differentiated landscape of violence and resource geographies, and fourthly, the criminalization proposition neglects the transnational dimensions of such wars. 
The terminology of "new war" and of "civil war" is problematic. I therefore refer back to a terminology proposed by Carl von Clausewitz, the great theoretician of war. Clausewitz suggested the term "Kleine Kriege" (small wars) to describe wars that are not fought between sovereign states (which are subject to international rules of warfare), but a variety of state and non-state actors (Clausewitz 1966). In small wars, the boundaries between combatants and non-combatants, between war and peace, between fighting, looting and plundering, between politics and economics, are often obscured, transgressed, re-defined. Most small wars are fought in difficult terrain, e.g. remote mountains, jungle or mega-cities. In that sense, the term "small" can be misleading as these small wars often have disastrous short-term and long-term consequences, although they are "little" wars, as Mbembe $(2001,87)$ puts it. Indeed, the term "small" (or Mbembe's "little") indicates that these wars tend to remain at the margins of strategic geopolitical interest, they involve few belligerents and relatively simple weaponry, their tactics may be rudimentary. Although the usefulness of the term has been debated (Daase 1998, Beaumont 1995, Olson 1995), Derek Gregory $(2010,158)$ has recently suggested its merits for lack of better terminology. As the genealogy of the term "Kleine Kriege” reminds us: small wars have been fought throughout human history - they are not "new" wars. ${ }^{4}$

\section{$\underline{\text { The resource curse proposition }}$}

\footnotetext{
${ }^{4}$ Of course, Max Boot's controversial The Savage Wars of Peace: Small Wars and the Rise of American Power makes the same point - that small wars have a long history (Boot 2002). But Boot's genealogy of American involvement in so-called small wars has also a normative premise - that the US should pay the price of involvement in such wars for the greater good. Boot's story is that of the entanglement of empire(s) in dirty, mundane - he calls it "savage" - types of warfare. Among military experts, the terminology of small wars is still being debated, largely in the tradition of the Small Wars Manual, published in 1940 by the United States Marine Corps (see, Small Wars Journal, http://smallwarsjournal.com/).
} 
A large and growing literature discusses the proposition that an abundance of lootable or exploitable natural resources creates economic incentives (Keen 1998, 2000) or “opportunities" (Collier 2000, Collier and Hoeffler 2004) to conduct warfare. In the 1990s, the literature on environment and conflict had written about the link between scarcity and violence (Homer-Dixon 1999). In this sense, the claim that resource abundance rather than scarcity triggered the onset of small wars was seen as a provocation to the established literature (e.g.: De Soysa 2002). Collier explained the new rationale as follows: while grievances about political problems (e.g. resource scarcity and the unequal distribution of resource access) can be found in many places, violent insurgency is likely to occur only in situations where there is the opportunity to finance it. Without such "opportunity", insurgency is not feasible.

It is here that two literatures merge: the one on the political economy of small wars and the so-called resource curse hypothesis (e.g. Auty 1995, De Soysa 2002, Fearon 2005, Lujala et al 2005, Ross 1999, 2004, 2006, Sachs and Warner 1995, $2001)^{5}$ or the "paradox of plenty" (Karl 1997) - a debate that has also attracted the attention of (economic) geographers (Bridge 2008, Le Billon 2001, 2004, 2008, Auty 2001, 2004, Korf and Engeler 2007, Watts 2003, 2004a, 2004b). The resource curse argument states that resource wealth, rather than benefitting a population, can in fact become a vice, when it encourages rent-seeking elites to establish a monopoly or oligopoly on resource exploitation making these elites independent from revenue through taxes and political support from the masses. Resource wealth thereby creates incentives and opportunities for insurgency as a means to monopolize resource rents through violence and war. These opportunities shape the preferences and motivations of individual actors, largely young men. When small wars are ongoing, different

\footnotetext{
${ }^{5}$ There are several variants of the resource curse proposition as well. This review focuses on those contributions that link the resource curse with violent conflict.
} 
warlords establish their realms of resource exploitation, thereby financing their troops and guarding their territorial control. This is also why small wars are difficult to end as insurgents turned warlords have little interest in giving up their revenue sources.

This literature has been shaped largely by large-N, cross-country statistical correlations between resource wealth and the onset, duration or ending of small wars and the incidence of violence therein. The empirical results of this research field have thus far remained inconclusive. ${ }^{6}$ Collier and Hoeffler's original proposition (Collier and Hoeffler 2002, 2004) about the statistical correlation between primary commodities, political instability and small wars has been increasingly contested by other quantitative researchers (Dixon 2009, Fearon 2005, Lujala et al. 2005, Ross 2004). Dixon (2009) therefore concludes that only on few parameters, a consensus has emerged within this research field.

In addition, the literature has been troubled by a number of semantic and conceptual conflations or unspecified micro-foundations (Brosza 2004, Cramer 2006, Dalby 2007, Ginty 2004, Kalyvas 2006, Korf 2006, Korf and Engeler 2007, Le Billon 2008, Mack 2002, O’Loughlin and Raleigh 2007, Raleigh et al. forthcoming): some authors, for example the early Collier (Collier 2000, Collier and Hoeffler 1998, 2002, 2004), whose work is discussed later in this article, were concerned with the economic opportunities for insurgency, i.e. what makes small wars feasible - this work addressed the onset of small wars (see also de Soysa 2002, Fearon and Laitin 2003). Other authors were more concerned with the duration of small wars and what explains

\footnotetext{
${ }^{6}$ See, for example: Basedau and Lay 2009, Brunnschweiler and Bulte 2009, Collier and Hoeffler 2002, 2004, 2005, De Soysa 2002, De Soysa and Neumayer 2007, Englebert and Ron 2004, Fearon and Laitin 2003, Fearon 2005, Fjelde 2009, Humphreys 2005, Lujala et al. 2005, Lujala 2009, 2010, Maconachie and Binns 2007, O’Loughlin and Raleigh 2007, Olsson 2006, Ross 2004, 2006, Snyder 2006, Thies 2010, Welsch 2008. And this list cannot claim to exhaust the breadth of a quickly expanding field.
} 
why these wars are difficult to end (e.g. the later Collier, i.e. Collier et al 2004, as well as, Elwert 1997, Fearon 2004, Jean and Rufin 1996, Keen 1997, 1998).

\section{Opportunity, feasibility, predation in small wars}

In this paper, I intend to discuss the underlying causal mechanisms (or: "microfoundations") that the literature employs to explain the link between resource curse and small wars. Central to these debates has been Paul Collier's famous distinction between greed and grievance as drivers of civil war onset. Originally, Collier suggested that rebellion was triggered by the pursuit of private goods, personal enrichment ("greed") rather than political grievances (Collier 2000, Collier and Hoeffler 2002, 2004). In Collier's model, violent insurgency occurs when there is opportunity to loot, when economic rents from exploiting natural resources can be captured and monopolized by (prospective) insurgents. Potential insurgents are primarily motivated by "greed" rather than by changing unjust political conditions ("grievances"), i.e. the analytical level is that of personal motivation.

The kind of resources that rebels seek to loot and the technologies of extraction they use can be manifold (Le Billon 2001, Snyder 2006), but in the most protracted small wars, these were often high value resources, such as diamonds or gold (Ross 2004). At this point, Collier's explanatory model links with the resource curse literature (de Soysa 2002, Collier and Hoeffler 2002, 2004) as the availability of "lootable" or exploitable resources (primary commodities) increases the vulnerability of a society to the incidence of small wars. If there are no exploitable or "lootable" resources, then rebels and combatants are not able to use them - and are thus unable to finance their warfare. 
More recently, Collier et al $(2009,3)$ have reformulated their model as "feasibility hypothesis" that proposes "where rebellion is materially feasible, it will occur". Already earlier, Fearon and Laitin $(2003,75$ f.) looked at factors that make insurgency more feasible and attractive. They agreed with Collier that financing is one determinant of viability or feasibility of rebellion, but for them, finance and opportunity to loot are not the only factors explaining feasibility of rebellion. They suggest that where incumbent rulers are weak, this encourages a rise of would-berulers who arrogate the power to "tax". In their later work, Collier et al. (2009) distinguish between feasibility, both financial and military, and motivation ("greed"). They write: "The feasibility hypothesis proposes that where rebellion is feasible it will occur" (Collier et al. 2009, 24). This explanation is compatible with different types of motivation; "greed" being only one of them.

Material (or financial) feasibility in Collier's sense may come from various sources, not only the looting of natural resources, but from taxing local populations or from non-local resource flows (e.g. Diaspora funding, Schlichte 2007). In Collier's opportunity model, resource flows stem from the exploitation of natural resources, which decreases the dependence of combatants on taxing local populations. Models of predation, in turn, examine the extraction and taxation basis of insurgency, i.e. how insurgents extract rents from the livelihoods of local people and how this relationship is based around a deal balancing rent extraction versus protection. Snyder's framework (Snyder and Bhavnani 2005, Snyder 2006) points to three components of extraction: the resource profile (lootable or non-lootable), the mode of extraction and the patterns of state spending, i.e. the trade-off of different forms of investment. Snyder alludes to the complex structures of extraction, predation and social (dis-) order. 
Some predation models have employed Mancur Olson's differentiation of roving and stationary bandits, which provides a simple model of the spatiality of rule (Addison et al. 2003, Azam 2002, Azam and Hoeffler 2002, Bates et al. 2002, Mehlum et al 2002, Skaperdas 2002, 2007). According to Olson, a stationary bandit has an interest to limit predation (and anarchic violence), because the social and economic losses resulting from predation will harm him/her economically by undermining the taxation basis: "If the leader of a roving bandit gang who finds slim pickings is strong enough to hold off a given territory and to keep other bandits out, $[\mathrm{s} /$ he can monopolize crime in that area $-[\mathrm{s} /$ he becomes a stationary bandit ... [and] a benefactor to those [s/]he robs" (Olson 2000, 7, 9). ${ }^{7}$ Azam (2002) and Azam and Hoeffler (2002) study a warlord's trade-off between looting and fighting during ongoing warfare (Azam 2002, Azam and Hoeffler 2002), Mehlum et al. (2002) developed cost-benefit models of plunder and protection - roving warlords plundering versus stationary bandits providing "protection" for the people they loot, while others modelled warlord markets where stationary bandits extract rents from the civilians on their territory and provide protection against roving or neighbouring stationary bandits.

While opportunity models and predation models are based in rational choice theory, they try to explain different social dynamics. The opportunity model originally explained the motivation to become a warlord, while the bandit model analyzes the incentives of bandits in ongoing warfare (although the opportunity model has now been applied to explain the duration of small wars as well). Bandit models aggregate individual actors into a category (the bandit) that entails a collective of individuals

\footnotetext{
${ }^{7}$ Of course, Olson's bandit model, which is quite abstract, should be read side-by-side with the empirically much richer work on warlord politics of William Reno (1999) or the work of Christopher Clapham, Morten Bøås and Kevin Dunn on African guerrillas (Clapham 1998, Bøås and Dunn 2007), which both would bring more nuance to patronage dynamics as well as political dynamics of so-called warlordism (see also, Richards 1996, Keen 2005 on Sierra Leone).
} 
(the rebel group), ${ }^{8}$ whereas Collier makes motivations, the collective action dilemma (or opportunity costs) of individuals central to his analysis (see Table 1).

Table 1: Opportunity, feasibility, predation

\begin{tabular}{|c|c|c|c|}
\hline & $\begin{array}{l}\text { Opportunity model } \\
\text { (greed) }\end{array}$ & Feasibility model & Predation model \\
\hline $\begin{array}{l}\text { Core explanatory } \\
\text { concept }\end{array}$ & Opportunity to loot & Feasibility of rebellion & $\begin{array}{l}\text { Extraction and } \\
\text { predation }\end{array}$ \\
\hline Rationale & $\begin{array}{l}\text { Motivation } \\
\text { (opportunity costs of } \\
\text { rebellion) }\end{array}$ & $\begin{array}{l}\text { Financial and military } \\
\text { feasibility }\end{array}$ & $\begin{array}{l}\text { Extraction versus } \\
\text { protection; } \\
\text { Stationary vs roving } \\
\text { bandit }\end{array}$ \\
\hline Phase in small war & $\begin{array}{l}\text { Onset, outbreak; later also } \\
\text { applied to duration and } \\
\text { ending }\end{array}$ & Onset, outbreak & (Onset), ongoing \\
\hline $\begin{array}{l}\text { Link to resource } \\
\text { curse paradigm }\end{array}$ & $\begin{array}{l}\text { Direct: statistical } \\
\text { correlation of resource } \\
\text { wealth and onset of small } \\
\text { wars as empirical } \\
\text { confirmation of the model }\end{array}$ & $\begin{array}{l}\text { Financial feasibility: } \\
\text { opportunity to loot, to } \\
\text { exploit commodities; }\end{array}$ & $\begin{array}{l}\text { Indirect: incentives to } \\
\text { nurture resources for } \\
\text { appropriation } \\
\text { (including the taxation } \\
\text { of civilians) }\end{array}$ \\
\hline Key authors & $\begin{array}{l}\text { Collier 2000, Collier and } \\
\text { Hoeffler 2002, } 2004 .\end{array}$ & $\begin{array}{l}\text { Collier et al 2009; } \\
\text { Fearon and Laitin } 2003\end{array}$ & $\begin{array}{l}\text { Extraction framework: } \\
\text { Snyder } 2006 \text {. } \\
\text { Original bandit model: } \\
\text { Olson } 2000 \text {. } \\
\text { Warlord models: } \\
\text { Azam 2002, Azam and } \\
\text { Hoeffler 2002, Bates et } \\
\text { al 2002, Mehlum et al } \\
2002 \text {, Skaperdas } 2002 \text {, } \\
2007 \text {. }\end{array}$ \\
\hline
\end{tabular}

The broadening of Collier's original "greed" model of motivation into models of opportunity, feasibility and predation has opened up the discussion that used to focus on primary commodities as "resource curse" to multiple factors that make rebellion feasible, including political, military and economic ones (Basedau and Lay 2009, Dunning 2005, Korf 2005, Le Billon 2008, Mehlum et al. 2006, Ron 2005, Snyder and Bhavnani 2005, Snyder 2006). While there continues to be a link between financial feasibility and the resource curse, the second component of feasibility military feasibility - has rather been linked with "geography", i.e. with terrain

\footnotetext{
${ }^{8}$ Bates et al (2002, 603), for example, acknowledge that they "ignore all issues relating to internal organisation of the actors, including collective action problems, decision-making processes and free riding. We simply assume two players."
} 
indicators and models of distance. Collier et al. $(2009,4)$, for example, write that "viability [which they seem to use interchangeably to feasibility; BK] is likely to be assisted by some combination of geography that provides safe heavens and an ineffective state." It is this conceptualization of "geography" that will be discussed in the next section.

The geography of opportunity, feasibility and predation in small wars Large-N, cross-country studies have been criticized for developing abstract explanatory frames that are not contextualized within actual landscapes of small wars, i.e. their micro-foundations are often underspecified. They are not developed to explain variation in landscapes of warfare, but rather to identify similarities. And they tend to treat the territories of small wars as homogeneous (O’Lear and Diehl 2007). In other words, these models ignore the geography of violence in small wars, which includes: the spatial dynamics of warfare, fighting, exploitation and coercion; the differentiations of "opportunities" and economic incentives across different resource types and actor categories; the time-space dynamics of accumulation and protection and their effects on small war dynamics and the trans-national dimensions of small wars and insurgent financing (Ballentine and Sherman 2003, Buhaug 2007, Dalby 2007, Flint 2005, Gregory and Pred 2007, Korf and Engeler 2007, Le Billon 2007, O’Lear and Diehl 2007, O’Loughlin 2005, O’Loughlin and Raleigh 2007).

A number of recent studies have attempted to capture this "geography" of small wars and they have done so in very different ways and with different analytical connections to the motivation, opportunity and feasibility models (also these links have not been made explicit in the literature). The meaning and framing of "geography" has been manifold. I have classified this research field into four 
approaches: (1) geography as rough terrain, (2) geography as (relative) location, (3) geography as resource concentration, and (4) geography as resource flow (cf. Table 2).

These different approaches each address some of the criticisms brought forward against the original opportunity, feasibility and predation literature (Table 2). Rough terrain models account for mountainous terrain as a locational factor that makes rebellion feasible. (Relative) location models use spatial grid models to disaggregate national territories to allow for a more fine-grained analysis of this "geography" than rough terrain models. Resource concentration models conceptualize the link between type and location of resources, technologies of exploitation and incentives, opportunities for and feasibility of insurgency. Resource flow models look into the transnational resource flows of conflict commodities and their link with global commodity chains. All these new approaches have made important contributions to understand "geography" in small wars, but we will also see that none has been completely convincing on its own terms.

\section{Approach 1: Geography as rough terrain}

In a number of econometric, cross-country models, "geography" in small wars has been conceptualized as rough terrain, being remote, sparsely populated, mountainous, being difficult to access and covered by forests. Rough terrain allows insurgents to operate guerrilla warfare, but rough terrain certainly does not "cause" small wars. A number of authors have tested these variables against the onset or duration of small wars (e.g. Collier and Hoeffler 2004, Collier et al 2004, DeRouen and Sobek 2004, 
Fearon and Laitin 2003, Fearon 2004, Rustad et al 2008). ${ }^{9}$ These rough terrain models are congruent with Collier's and Fearon and Laitin's notion of feasibility of war, mainly its military feasibility. However, they have produced mixed results: Dixon (2009) finds that the variable "mountains" has yielded contradictory results across a section of studies employing this variable. Collier and Hoeffler (2004), for example, do not find a correlation between rough terrain and the incidence of small wars, whereas Fearon and Laitin $(2003,85)$ suggest that "mountainous terrain is significantly related to higher rates of civil war." In their later study, Collier at al. $(2009,16)$ largely concur with Fearon and Laitin (2003), but the statistical significance is not strong. De Rouen and Sobek (2004) claim that higher forest cover increases the likelihood of prolonged conflict.

The key weakness of rough terrain analyses is that they correlate aggregate data on the state-level, whereas terrain factors are often confined to small parts of a country. The proxies are generated "at the wrong level of measurement: the nation state" (Buhaug and Lujala 2005, 404). Raleigh et al. (forthcoming, 3) conclude that: "many studies incorporating sub-national indicators have substituted simplified 'geometries' for complicated geographies, relying on abstract and vague notions of distance ... or crude terrain indices." At the same time, the rough terrain indicators have provided evidence for the (military) feasibility proposition rather than the financial opportunity or feasibility proposition, i.e. they do not say anything on motivations for rebellion.

\footnotetext{
${ }^{9}$ Braithwaite (2006) discusses the "geographic spread" of militarized disputes and finds terrain indicators to be significant, but he is concerned with inter-state dispute, not with small wars. That is why his work is not discussed here.
} 
Approach 2: Geography as (relative) location

In response to these criticisms, the geography as (relative) location adopts a spatially disaggregated approach to (1) terrain and resource characteristics and (2) conflict events. This literature has either focused on absolute location within a spatial grid, or as relative location (“distance"), relative to a country's capital or centres of economic or political powers.

Together with different co-authors, Buhaug refined the spatial analysis of war dynamics within the spatial container of a war, i.e. looking at spatial scales below the state-level (Buhaug and Lujala 2005, Buhaug and Rød 2006). Buhaug and Lujala (2005) run a comparison of "geography" factors on state-level and on "conflict level" and conclude that "the amount of mountainous terrain in the country is positively associated with the duration of conflict, whereas densely forested countries tend to have shorter conflicts, ceteris paribus" (p. 412, italics in original). In another study, one confined to African civil wars, Buhaug and Rød (2006) differentiate between a) territorial conflict that is more likely in sparsely populated regions near the state border, at a distance from the capital, and without significant rough terrain and b) conflict over state governance that is more likely to occur in densely populated regions near diamond fields and close to the capital. Location factors are also prominent for Lujala (2010), who concludes that rebel access to gemstones and hydrocarbons increases conflict duration, in fact "the mere presence" (Lujala 2010, 26) of hydrocarbon reserves increases this relationship, which he interprets in line with Collier's opportunity model.

Gates (2002) shows how distance and geographical spread of rebel forces with regard to a government's stronghold affects rebel recruitment and allegiance. Buhaug and Gates $(2002,418)$ use spatial econometrics to analyse how "geographical factors 
affect the location, relative to the capital, and scope (measured conflict area) of armed conflict." Their dependent variables are the scope and location of small wars, not the outbreak, incidence, duration or ending of war. They define the location of fighting within a country as the distance between the capital city - assumed to be the centre of power - and the conflict centre point. Scope is conceptualized as "the geographic domain of the conflict zone, measured as the circular area centred around the conflict centre and covering all significant battle zones" (Buhaug and Gates 2002, p. 421). They find that the scope of conflict is associated with a number of "geographical factors" (p. 430), such as the total land area of the country, whether or not the conflict zone is adjacent to the border of a neighbouring country and whether or not natural resources are located in the conflict zone. With regard to location as conflict-capital distance, Buhaug and Gates (2002) conclude that the type of rebellion and of the rebel group influence where the conflict will be located and suggest that secessionist and identity-based wars tend to be located further away from the capital than other types of conflict. Buhaug and Lujala $(2005,412)$ add that small wars that occur at a distance from the capital are more likely to turn into protracted contests.

But this spatial information used in these studies still tends to be too coarse to allow the study of localized accounts of violence (O'Loughlin and Witmer 2010). The trend towards spatial disaggregation has been further facilitated by the availability of new data for quantitative analysis (Cederman and Gleditsch 2009), such as the ACLED (Armed Conflict Location and Events Dataset) - that disaggregates internal conflicts into individual events (Raleigh et al 2009), the Correlates of War project and the Uppsala Riot dataset (the latter being the database for Buhaug's studies above). ${ }^{10}$

\footnotetext{
${ }^{10} \mathrm{See} \mathrm{http://www.correlatesofwar.org/} \mathrm{and} \mathrm{http://www.pcr.uu.se/research/UCDP/index.htm}$
} 
The ACLED database, for example, allows quantitative researchers to track geocoded data on violent events and to link details of resource use to each such events.

Raleigh and Hegre (2009), using ACLED, applied a "grid square" approach to study the relationship between country size, population numbers (and spatial concentrations) and conclude that conflict events tend to have "frequencies in proportion to the size of the population in a given location $[. .$.$] where populations$ cluster locally" (p. 237). They also claim that the grid square approach using ACLED data is suitable also to test hypotheses regarding the availability of 'lootable' resources. Hegre et al (2009) explore the link between local levels of wealth and the location of actual fighting in a conflict using Liberia as a case study. The authors conclude that violent events were more frequent in richer locations within Liberia, which they find supports Collier's opportunity model, albeit results are not “completely contradictory to 'grievance' accounts [...] both aggrieved and greedy rebels have an incentive to target the wealthy locations where hostilities will pay off' (Hegre et al. 2009, 620). O'Loughlin and Witmer (2010) use event coded data to analyze and show the spatial diffusion of violent events in Chechnya. They identify "hot spot" locations of violence, and show that forested areas have more, while areas with high Russian population ratios have less violent events. However, they also write that the lack of data for predictive variables (especially on material wealth) did not allow them to run an effective test of the opportunity model or alternative explanations (the greed vs. grievance controversy) (O'Loughlin and Witmer 2010, p. 48). O'Loughlin et al. (2010) do a similar event coding, this time using ACLED data, for the Afghanistan-Pakistan wars of 2008-2009, and map the non-random and concentrated geography patterns of violence. 
The geography as location approach has worked on two levels: (1)

disaggregating the resource (the independent, explanatory variable), e.g. in those studies that look at the location of populations, wealth or resources, and (2) disaggregating violence (the dependent variable), e.g. those studies that look at conflict events (using the ACLED dataset). These and other studies on disaggregating small wars (Buhaug et al 2009, Cederman et al 2009, Hegre et al 2009, Murshed and Gates 2005, Weidmann 2009, Weidmann et al. 2010) often resort to Collier's opportunity model as well as rebel capabilities - what Collier calls "feasibility": conditions that make insurgency and warfare feasible, e.g. by providing places to hide or withdraw, by enabling taxation of non-belligerents and exploitation of natural resources (including the opening of marketing channels to sell such resources). Weidmann (2009), for example, studies "group geography" (p. 527), i.e. the concentration of a social group over a territory, and constructs a causal mechanism between a group's settlement pattern in physical terrain and its capacity for fighting (or organizing collective action). He suggests that opportunities to organize collectively make violent conflict more likely.

The geography as location approach operates within the greed-grievance opposition (either-or) and provides a spatialized methodology (e.g. spatial econometrics and GIS technologies) to test these opposing propositions. Disaggregating the territory of warfare into spatial grids deconstructs the spatial container within which cross-country econometric studies had based their datasets and proxy indicators, in line with John Agnew's famous critique of the territorial trap (Agnew 1994). Such spatial disaggregation concurs with the empirical observation that small wars are often spatially confined and not uniformly spread over a nation's territory. At the same time, most studies still correlate certain terrain or location 
factors with events, but the explanatory models of rebel behaviour are then derived from those correlations - and linked to an explanation largely in line with the opportunity or feasibility model (or alternative explanatory models, such as relative deprivation, horizontal inequalities, etc.), although sometimes, such a link is rather implicit than explicit. However, by spatially disaggregating conflict spaces, these studies cannot run large- $\mathrm{N}$ tests of country or conflict cases as done in the work of Collier and colleagues, but are confined to small-N comparisons of conflict or country cases (although doing large-N regressions on spatially disaggregated events or factors in these cases).

\section{Approach 3: Geography as resource concentration}

The geography as resource concentration approach spatializes the resource category and differentiates locations and types of resources, types of governance and scales of resource flows. Le Billon has provided an influential categorisation of how the properties of a resource, its location and the required technologies of exploitation impact upon the dynamics of rebellion and warfare (Le Billon 2001, 2004, 2005a). These categories are then translated into a typology that links particular types of insurgency and warlordism with the geographies of "lootable" or exploitable resources. Two categories are central in this typology creating four different types of resource violence: first, the relative location of the resource (vis-à-vis the power centre) and second, the resource concentration. With regard to resource location, Le Billon writes that proximate resources are close to the centre of power and firmly under the grip of a government, whereas distant resources are located in remote territories along porous borders and more prone to be captured by rebels. 
Le Billon's typology (2001) combines the geography as location model with a differentiation between point and diffuse resources. He suggests that point resources located in proximity to the power centre are more likely to be associated with a coup d'état (or foreign intervention), whereas diffuse, distant resources are more likely to trigger warlordism. In fact, Le Billon's analysis indicates that the physical properties of a resource and the material transformations that a resource has to undergo to become a high-value commodity are important determinants for its attractiveness for looting or exploitation (see also, Lujala 2009, Ross 2004). Also, the properties of the resource determine whether or not they are lootable with simple technologies or require more sophisticated and larger-scale technologies for their exploitation.

A similar typology has been suggested by Richard Auty (Auty 1995, 2001, 2004, based on Sachs and Warner 1995; see also Welsch 2008). Auty's typology links resource endowment with regime types using Olson's bandit model and its four categories (roving bandit, stationary bandit, oligarchy and democracy). His staple-trap model suggests that resource-rich countries tend to spawn predatory political states as the incentive for a government to provide public goods, as opposed to capturing rents, increases with decreasing access to natural resource rents as it makes elites more independent from the electorate. Auty disaggregates the risk of small wars and argues that the socio-economic linkages of the types of resources (diffuse, point) and the value per weight ratio foster specific types of rebellion or rentier states. Proximity to porous borders is another factor that, according to Auty, enhances the mobility of rents and thereby encourages rebellion at the state's periphery.

Both, Le Billon's and Auty's typologies have been useful to disaggregate and differentiate the link between resource availability, economic incentives and capabilities to loot or exploit resource rents. They also indicated that there are 
different patterns of violent conflict. Both link a typology of resource characteristics and location with social outcomes, though Le Billon emphasizes that he does not understand these relationships to be deterministic, rather that "resources provide a context for political mobilization as well as the motivations, strategies, and capabilities of belligerents" (Le Billon 2004, 15; my emphasis). "Motivations, strategies and capabilities" link up with Collier's opportunity and feasibility concept, but the exact temporalities of these opportunities and conditions of feasibility remain underexplored: do these apply to incentives to start insurgency or capabilities to run a war economy or both? Auty's bandit model, in turn, points to the changing elitecitizen relations depending on resource wealth that makes elites more independent from popular support.

Approach 4: Geography as resource flow

The geography as resource flow approach spatializes resource flows across scales and applies commodity chain analysis to trace economic opportunities of resource appropriation across scales. One of Auty's propositions was that proximity to borders enables mobility of rents and resources. This observation encouraged analysis of the transnational commodity chains of "conflict commodities.” Most small wars fought around resources - the "resource wars" - have a significant international dimension since high value resources gain their value only when sold on the international (black) market (Bridge 2008, Cooper 2002, Le Billon 2006, 2008, Ossenbrügge 2007). These conceptualizations explicitly used concepts developed in economic geography (commodity chain, production networks) to study economic opportunities and incentives in small wars across spatial scales and networks. While previous work had largely remained trapped in a container space of state or sub-state units and focused 
on local opportunity and feasibility characteristics and local availability of precious resources for looting or exploitation, the resource flow approach showed that opportunities, incentives and resource flows are embedded in transnational economic flows and global market mechanisms that allow these resources to be marketed and sold, and thereby to become financially attractive for looting.

Le Billon $(2006,2008)$ suggested that the geography of resource wars is not only defined by frontlines in the production area, but also by spaces along the commodity chain; the spatiality of resources has mining and marketing contexts. He studied how the commodity chains of "blood diamonds" are located within broader geographies of vulnerability, risk and opportunity in the war-affected countries (Le Billon 2008). Le Billon distinguishes the geography of vulnerability (being vulnerable to violent conflict due to diamond wealth), the geography of risk (territorialization of regulatory regimes) and the geography of opportunity (interconnectedness between actors and flows of material goods across spatial scales). In this sense, Le Billon's model discusses spatialized economic incentives, i.e. material feasibility.

An interesting strand of this kind of research investigates the commodity chain of war resources, e.g. diamonds, and how "illegal" production enters the global ("legal") economy. Le Billon's example of blood diamonds also illustrates the West's geographical imagination of danger (Dalby 2004) that is associated with resources from specific locations, such as diamonds from West Africa (Le Billon 2006). This leads to a discursive differentiation of dirty and pure diamonds. For example, Le Billon argued that campaigns against blood diamonds displaced alluvial diamonds, which are often exploited by small-scale labourers, from the world market that became increasingly dominated by industrial exploitation dominated by large multinational corporations, thereby creating "good" and "bad" diamonds. But such 
geographical imaginations are resource dependent. Oil, for example, tends to create less moralizing imaginations among Western consumers (Bridge 2008, Ossenbrügge 2007), but sometimes triggers what Watts calls resource nationalism (Watts 2003).

The resource flows approach has been instrumental to show the global entanglements of "conflict commodities" with global markets and consumerism. It also indicates that the geography of resources needs to favour a commodification of primary commodities into marketable goods that are to be transported into places where they can be integrated into global market chains. This international dimension of the resource curse had so far been under-examined in opportunity and feasibility models who had focused primarily on local conditions and local factors of "geography". At the same time, resource flow models have a close link to the discussion on motivation (incentives), opportunity and (material) feasibility of insurgency.

Table 2: The "geography of opportunity, feasibility and predation" in small wars

\begin{tabular}{|c|c|c|c|c|}
\hline & Approach 1 & Approach 2 & Approach 3 & Approach 4 \\
\hline & $\begin{array}{l}\text { Geography as } \\
\text { rough terrain }\end{array}$ & $\begin{array}{l}\text { Geography as } \\
\text { (relative) } \\
\text { location }\end{array}$ & $\begin{array}{l}\text { Geography as } \\
\text { resource } \\
\text { concentration }\end{array}$ & $\begin{array}{l}\text { Geography as } \\
\text { resource flow }\end{array}$ \\
\hline $\begin{array}{l}\text { The } \\
\text { conceptualization } \\
\text { of geography }\end{array}$ & $\begin{array}{l}\text { "Rough terrain", } \\
\text { Mainly military } \\
\text { feasibility }\end{array}$ & $\begin{array}{l}\text { Resource } \\
\text { location; } \\
\text { Conflict events } \\
\text { location; }\end{array}$ & $\begin{array}{l}\text { Resource type, } \\
\text { four conflict types } \\
\text { (Le Billon), } \\
\text { different governance } \\
\text { types, bandit models } \\
\text { (Auty) }\end{array}$ & $\begin{array}{l}\text { Dirty and pure } \\
\text { resources, } \\
\text { consumption and } \\
\text { production of } \\
\text { resources }\end{array}$ \\
\hline Spatial concepts & $\begin{array}{l}\text { Scope, } \\
\text { terrain, remoteness }\end{array}$ & $\begin{array}{l}\text { Location; } \\
\text { relative } \\
\text { location } \\
\text { (distance) }\end{array}$ & $\begin{array}{l}\text { Relative location; } \\
\text { point-diffuse } \\
\text { resources (spatial } \\
\text { diffusion or } \\
\text { concentration) }\end{array}$ & $\begin{array}{l}\text { Commodity chain, } \\
\text { transnational flows }\end{array}$ \\
\hline Methodology & $\begin{array}{l}\text { Cross-country } \\
\text { econometrics; } \\
\text { spatial } \\
\text { econometrics }\end{array}$ & $\begin{array}{l}\text { GIS, spatial } \\
\text { econometrics }\end{array}$ & Typology & Typology \\
\hline $\begin{array}{l}\text { Spatial scale of } \\
\text { explanation }\end{array}$ & $\begin{array}{l}\text { Nation-state level, } \\
\text { more recent } \\
\text { studies also below } \\
\text { nation-state level } \\
\text { (see next column) }\end{array}$ & $\begin{array}{l}\text { Several scales, } \\
\text { but often supra- } \\
\text { state level }\end{array}$ & (Sub-) state-level & $\begin{array}{l}\text { From local to } \\
\text { global; } \\
\text { Commodity chain }\end{array}$ \\
\hline
\end{tabular}




\begin{tabular}{|c|c|c|c|c|}
\hline $\begin{array}{l}\text { Contribution to } \\
\text { the geography of } \\
\text { small wars }\end{array}$ & $\begin{array}{l}\text { Integrates terrain } \\
\text { indicators into the } \\
\text { analysis. }\end{array}$ & $\begin{array}{l}\text { Spatially } \\
\text { disaggregates } \\
\text { quantitative } \\
\text { methods; } \\
\text { localizes } \\
\text { resources or } \\
\text { violent events }\end{array}$ & $\begin{array}{l}\text { Spatializes the } \\
\text { resource categories }\end{array}$ & $\begin{array}{l}\text { Spatializes } \\
\text { resource flows }\end{array}$ \\
\hline $\begin{array}{l}\text { Motivation, } \\
\text { opportunity, } \\
\text { feasibility }\end{array}$ & $\begin{array}{l}\text { Mainly military } \\
\text { feasibility }\end{array}$ & $\begin{array}{l}\text { military and } \\
\text { financial } \\
\text { feasibility }\end{array}$ & $\begin{array}{l}\text { Financial feasibility, } \\
\text { military feasibility; } \\
\text { gesturing towards } \\
\text { resource curse } \\
\text { literature }\end{array}$ & $\begin{array}{l}\text { Opportunity, } \\
\text { incentives, } \\
\text { financial } \\
\text { feasibility; } \\
\text { Gesturing towards } \\
\text { resource curse } \\
\text { literature }\end{array}$ \\
\hline Key references & $\begin{array}{l}\text { Collier and } \\
\text { Hoeffler 2004, } \\
\text { Collier et al 2004, } \\
\text { DeRouen and } \\
\text { Sobek 2004, } \\
\text { Fearon and Laitin } \\
\text { 2003, Fearon } \\
\text { 2004, Rustad et al } \\
\text { 2008; } \\
\text { Buhaug and Gates } \\
2002\end{array}$ & $\begin{array}{l}\text { Buhaug and } \\
\text { Lujala 2005, } \\
\text { Buhaug and } \\
\text { Rød 2006; } \\
\text { O'Loughlin and } \\
\text { Witmer 2010; } \\
\text { O'Loughlin et } \\
\text { al. 2010; } \\
\text { Raleigh and } \\
\text { Hegre 2009, } \\
\text { Hegre et al } \\
\text { 2009; } \\
\text { Cederman et al } \\
\text { 2009, } \\
\text { Weidmann } \\
\text { 2009 }\end{array}$ & $\begin{array}{l}\text { Le Billon 2001, } \\
\text { 2004; } \\
\text { Auty 2001, 2004; } \\
\text { Lujala 2010, }\end{array}$ & $\begin{array}{l}\text { Le Billon 2007, } \\
\text { 2008: } \\
\text { Ossenbrügge } \\
\text { 2007, etc. }\end{array}$ \\
\hline
\end{tabular}

Four agendas: The geography of rule, violence and affect in small wars

The four approaches discussed above have significantly advanced the literature on resources, violence and small wars through emphasizing spatial disaggregation of events, resource types and flows (Table 2). And yet, the semantics of motivation, opportunity and feasibility and the discussion of "conflict commodities," "resource wars" and "resource curse" foreclose important mechanisms of the "microfoundations" of small wars, which will be discussed in this section.

First, the literature has often conceptualized greed versus grievance in oppositional terms (as either-or) - as private versus public (or political) motivations. This opposition has been central to Collier's opportunity model. More recent work has 
suggested that it is the linkages between greed and grievance across multiple scales, connections and networks that create complex geographies of violence, coercion and rule in small wars (Ballentine and Sherman 2003, Cramer 2002, 2006, Goodhand 2003, Kalyvas 2003, 2006, Korf 2005, Murshed and Tadjoeddin 2009). Stathis Kalyvas and Michael Watts address the interactions between greed and grievance in their studies of the politics in small wars. While Kalyvas remains broadly loyal to the rational choice paradigm, that has been Collier's home, Watts rather draws on the governmentality literature.

Second, agency, opportunity and feasibility in small wars has a variegated geography bringing into contact a wide range of actors in spaces of negotiation, coercion, subordination, avoidance, resistance and patronage. The literature reviewed above alludes mainly to a single actor category, that of the rebels, soldiers or warlords. Other types of actors, e.g. “ordinary" people, non-combatants, local middlemen, traders, farmers, fishing folk, women, children, politicians, bureaucrats, chiefs, religious leaders, and their agencies are thereby written out of the analysis. Furthermore, agency is often conceived as rational, strategic, tactical, but the affective dynamics of fighting, violence and repression is thereby neglected. Two fields of study are relevant here: literature that explores the subaltern geographies of small wars and writings that discuss rationality and madness in warfare.

\section{Kalyvas: zones of violence and control}

Stathis Kalyvas starts with a critique of the research field and its lack of "microfoundations" (Kalyvas 2003, 2006, 2008), the causal mechanisms that explain statistical correlations to address "the problems of measurement and interpretation" of cross-national level econometric studies (Kalyvas and Kocher 2009, 335). Many 
studies on opportunity, feasibility and predation did not have any primary empirical evidence about the motivations, strategies and preferences of belligerents (Kalyvas 2008, 405), but rather used proxies, such as conflict event data. Kalyvas instead propagates a conceptual disaggregation of violence and conflict. His focus is on the patterns of homicidal violence as distinct from the logic of conflict in general, a theme also taken up by other authors (e.g. Straus 2006, Verwimp 2006, Weinstein 2007). Kalyvas proposes that there is an interaction of political and private identities, motivations and actions (or, that greed and grievances are not separable). Kalyvas argues that "analysis of the dynamics of civil war $[\ldots]$ is impossible in the absence of close attention to local dynamics" $(2003,481)$.

What makes Kalyvas' contribution interesting is that he develops a model of the geography of violence and control. Central to his conceptual model are the terms “cleavage", "alliance" and "center-periphery". Alliance, writes Kalyvas, "allows for multiple rather than unitary actors, agency located in both center and periphery rather than only in either one, and a variety of preferences and identities as opposed to a common and overarching one" $(2003,486)$. Cleavages are symbolic formations that simplify and streamline a variety of local conflicts and master-narratives in small wars. Kalyvas' prime interest is now in the geography of violence and control: who controls which territories and where do events of violence occur? The use of violence, according to Kalyvas, is mostly selective (rather than indiscriminate) and bounded by the nature of control of belligerent groups over a specific territory. For Kalyvas, the likelihood of (selective) violence is a function of control. He distinguishes a typology of five-zone continuum from zone 1 (total incumbent control) to zone 5 (total insurgent control). Kalyvas' prediction is that the distribution of selective violence is likely to peak in zones 2 and 4, where either group exercises hegemonic, but not total 
control, whereas zones of complete control by one side will be largely free of violence, though not repression. Kalyvas has confirmed these predictions in his landmark study on the Greek civil war (Kalyvas 2006) and, more recently, on the Vietnam war (Kalyvas 2008, Kalyvas and Kocher 2009).

Kalyvas' propositions basically study processes of "territorializing domination" (Mbembe 2001, 85). But "geography" in Kalyvas' conceptualization is reduced to a center-periphery dichotomy and a container-type territoriality of "zone". His five zone model reproduces a duality of incumbent versus insurgent, although in a number of small wars, there has been a proliferation of belligerent groups and this boundary distinction has rather been confused. Moreover, Tarrow $(2007,592)$ finds that Kalyvas reifies violence: "the interaction between center and periphery focuses on violence," but tends to ignore the relationship between violent and nonviolent forms of contention in the development of alliances. Kalyvas seems to suggest (2006, 22) that contentious politics takes place during peace and violence occurs during war. This proposition fails to acknowledge that many mechanisms of contention are similar during peace and war (Spencer 2007): the "distinction between a state of war and a state of peace is increasingly illusory" (Mbembe 2001, 89).

\section{Watts: governable spaces}

Michael Watts' work on ungovernable spaces in Nigeria's oil delta opens up some of the points that Kalyvas' ontology of violence rather forecloses. At the same time, Watts' study links up with the resource curse literature and its link to the opportunity, feasibility and predation literature. ${ }^{11}$ Watts' genealogy of oil governmentality departs from Collier's opportunity model and traces "the variety of violences engendered by

\footnotetext{
${ }^{11}$ Although some may question whether Watts' empirical case is a small war, I refrain from this discussion as I am interested in the analytical model that Watts uses in his analysis of resources and violence.
} 
oil (not just civil war or rebellion)" (Watts 2004a, 53), the entanglements of oil wealth and the complex history of social (dis-) order in Nigeria with its spaces for violence, claims-making and community building. In this story, oil is as much a biophysical entity, a commodity, as it is a source of imagination and meaning. Watts' analysis emphasizes the simultaneous production (and reworking) of different forms of preexisting rule and governable space(s) that evolve as a result of the insertion of oil revenue into the Nigerian political economy (2004a, p54) and result in civil vigilantism. In this sense, Watts provides a typology of the geography of violence and control, but one that has also space for contentious politics.

Two aspects are significant in Watts' analysis. Firstly, he provides a finegrained analysis of the transformative effects of oil on various governable spaces with their different rationales and internal contradictions and paradoxes. Secondly, Watts studies the agencies of different types of actors. For example, he explains how indigenous chiefs organized youth militantism in order to squeeze out more benefits from powerful multinational oil companies. The chiefs' strategy went out of control and a kind of "Mafia" - Isongoforo - controlled much of the monies appropriated from the companies through the arms with which they exercised control. This civic vigilantism emerged from the "opportunities for appropriating ... resources" (Watts 2004a, 64).

Watts' analytics go beyond Collier's opportunity model. In what he calls "space of indigeneity", oil serves as an elitist endeavour for ethnic claims-making and rights talk (Watts 2004a, 71). Oil also kept Nigeria together as a nation - and fragmented it. While the (nation) state used oil revenues to build a nation, various communities used oil wealth to activate community claims and thereby made "the Nigerian National Symbolic ... simply a big lie" (Watts 2004a, 74). Oil revenues 
provide rents, which increase competition for power, offices and politics. Within this competition, claims to the rightness of access and control over resources and its regulation become central.

I think Watts' most important point is that conflicts and politics (in Nigeria) emerge from an oil complex that is spatially heterogeneous and not easily encompassed by ideas of opportunity, feasibility, predation, looting, rebellion or incentives for violence only. Watts writes that oil becomes an idiom for "doing politics" (Watts 2004a, 76). This politics is embedded in an already existing landscape of power and politics - at this point, he concurs with Kalyvas. But Watts' conceptual model of three governable spaces wherein struggles over geography are fought, remains surprisingly static; rather, it is not only within, but also at the interfaces of these different governable spaces, where struggles are fought, lives are lived and politics takes place - as much as predation. While Watts looks at the "simultaneous production of differing forms of rule and governable space ... which work against, and often stand in direct confrontation to each other", his analysis leaves us unclear about the mechanisms of how these governable spaces merge, coincide, overlap to create the ragged, unstable, ungovernable spaces (Korf et al. 2010).

\section{Subaltern geographies of small wars}

The opportunity and feasibility models of insurgency constructs an analytical focus on one actor category, that of the (potential) insurgent and his or her motivations, incentives and capabilities. This reading tends to neglect a number of other types of actors that play a role in small wars, those of "ordinary" people. Small wars, while providing a break with "peace", also produce a number of continuities in political alliances, social and economic networks prior to the conflict - rarely do they 
constitute a complete rupture with the past (Lubkemann 2007). Indeed, a number of more recent studies have broadened the analytic lens towards the many others who are also part of and shape struggles over geography in small wars (Bohle 2007, Bohle and Fünfgeld 2007, Collison 2003, Fünfgeld 2007, Gaasbeek 2010, Goodhand et al 2000, Kalyvas 2006, Keen 2005, Korf 2004, 2005, Korf and Fünfgeld 2006, Kurtenbach und Lock 2004, Lubkemann 2007, Macamo 2006, Nordstrom 2004, Richards 2005, Utas 2005, Vigh 2006). Many of these studies suggest that non-belligerents navigate through the difficult terrain of markets or oligopolies of violence, develop their own "weapons of the weak" - to borrow a famous term from James Scott (1985) - and make use of opportunities for economic gains where they find these; or display strategies to keep belligerents at arm's length in order to survive, to safeguard precarious livelihoods or to actively engage in clientele networks.

These subaltern geographies of small wars indicate the shadows of war (Nordstrom 2004), the ambivalences of the political economy of war, where survival and war economies are closely intertwined (Bohle 2007, Collison 2003, Fünfgeld 2007, Korf 2004, Lunstrum 2009, Macamo 2006, Korf 2005, Korf et al 2010, Lubkemann 2007, Nordstrom 2004, Richards 2005, Schlichte 2009), where "greed”, "opportunity", as well as "grievances" and "vulnerability" are not confined to either "belligerents" or "civilians." While Kalyvas' analytics has focused on violence, the subaltern geographies of small wars point to the intricate links of violence with contentious politics, coercion, consent, avoidance, resistance and vulnerability that has been shown in Watts' analysis, although he is less interested in subaltern agencies.

Studies on subaltern geographies have been strong in underlining the variegated geographies of feasibility and opportunity and the complex web of 
relations, economic flows, inter-dependencies across scales and connections that political economies of war and violence nurture. And yet, the subaltern geographies literature may have been overdoing its case by its tendency to promote an image of flow and navigation (e.g. Vigh 2006, Utas 2005), which celebrates agencies and perhaps downplays the structural constraints within which people's agencies flow. ${ }^{12}$

\section{Rationality and madness}

Violence has an incalculable dimension, can go out of hand - the "madness" that is not rational. When David Keen wrote about "a rational kind of madness" (Keen 1997), he suggested that what appeared to be mad (atrocities, mindless violence, etc.) was rational for war entrepreneurs to achieve their ends. Keen's suggestive terms complies with a wide array of literature, including Collier's greed model or Elwert's notion of "markets of violence" (Elwert 1997) and the opportunity, feasibility and predation paradigm. Violence is used to achieve something (monopolize rents, for example). These contributions propagate a rationalist conception of violence, which downplays the dynamics of affect and emotions in violent struggle, in organizing insurgency, in defining friend and foe, in demarcating territories, in identity struggles over belonging, but also in generating vulnerabilities (Cramer 2002, Korf 2006).

Legitimizations and rationalizations of war and violence may play with the mobilization of fear, rage, anger, and hope in relation to threat and opportunity (Keen 2005; Schlichte 2009, Spencer 2007, Weinstein 2007). Collier writes that belligerents may deploy grievance discourses to bind fighters (Collier 2000). Stathis Kalyvas suggests that logics of violence are often driven more by local grievances that utilize the master grievance to settle old scores (Kalyvas 2006; also: Korf 2005, Korf and

12 For a more detailed critique of this problematic emphasis on agencies and navigation, see Korf et al. (2010). 
Fünfgeld 2006, Lubkemann 2007, Richards 1996). This complies with David Keen's work on Sierra Leone where "part of the impetus for atrocities in Sierra Leone's civil war was resentment at neglect and abuse (and a concomitant desire for respect ...) [... and] a perception within various fighting groups that civilians had somehow 'turned against' or 'betrayed' them" (Keen 2008, 56, Keen 2005). Georg Elwert suggests that the generation of fear - the fear of becoming a victim and the resulting feeling of revenge - is "a particularly cost-effective form of mobilising troops" (Elwert 1999, 90). Revenge creates retaliation and an escalation of violence that war entrepreneurs can use for their economic gains.

However, this reading of economic rationalities in steering violence overlooks the affective dynamics that war nurtures. Certainly, belligerents utilize "grievances", steer emotions and foster longing for respect, they play with fear and revenge for their “rational" purposes. But violence can get out of control and develop a dynamic beyond calculation and rationality. Ernst Jünger once famously described the addictive force that can emerge in the midst of fighting, violence and destruction, a reading recently rediscovered in his diaries from World War I (Jünger 2010). Chris Hedges has been influential in writing about how violence in warfare can become addictive or exhilarating for belligerents or other perpetrators of violence, how it shapes a culture of war, how war becomes a drug (Hedges 2002). Wolfgang Sofsky suggests that those who kill escape the compulsion to control themselves (Sofsky 2003). Feldman's work on the prosthetics and aesthetics of terror and violence, the ecology of fear and anxiety in the Irish civil war is also suggestive (Feldman 1997). It is this phenomenology of the incalculable, perhaps subconscious, irrational in the geography of violence that requires more careful and systematic work. Indeed, John Agnew comes to the conclusion that the literature on the phenomenology of affect and 
violence in small wars (and other wars) is still sketchy (Agnew 2009) and I concur

with his reading that this is a research agenda requiring more careful development. ${ }^{13}$

\section{$\underline{\text { The telluric geographies of small wars }}$}

Stathis Kalyvas has reframed the two competing interpretative concepts of greed versus grievance that have been so influential in the literature on small wars as Hobbesian versus Schmittian interpretations (2003, 475f.): The Hobbesian inspiration characterizes small wars in terms of breakdown of authority and privatization of violence; the Schmittian frame emphasizes group loyalties, enmity and collective beliefs. ${ }^{14}$ Small wars, I have suggested, entail much more than belligerents and their opportunities as the opportunity, feasibility and predation framework suggests. Explaining the onset and dynamics of small wars and violent insurgency purely through the lens of opportunity, feasibility and predation, confining it to a rationalist conception of the properties of insurgents and belligerents clearly writes out the Schmittian dimension of the political pertinent in small wars. Insurgency is not only the continuation of economics with other means; it is not only about feasibility in a material or financial sense.

I concur with Kalyvas who propagates a framework that combines the Hobbesian and the Schmittian interpretations. I have criticized the "geography of opportunity, feasibility and predation" literature for failing to address this "and": the

13 While, at the moment, we still have only sketchy evidence, accounts and data on the link between affect and violence in small wars, there is some materials with a focus on affect and violence, but without explicit focus on small wars, that could stimulate this agenda: Valentine Daniel's exploration on suffering and murmuring (Daniel 1996), writings on the "aesthetics" of violence, the addictive, suicidal drive into death that suicidal attackers may experience (Appadurai 2007, Enzensberger 2006, Sloterdijk 2006, Thrift 2007), although it appears to me that much of this work is based on shaky empirical data, if at all; finally, the important material compiled in Das et al. (2000) and in ScheperHughes et al. (2003), though these two edited collections explore a much broader array of situations and contexts of violence, terror, coercion, including tribal warfare, ethnic riots, "state amok" and the holocaust.

14 Kalyvas refers here to Carl Schmitt's famous definition of the political as the friend-enemy distinction, as found in Schmitt's The Concept of the Political ([1932] 1996). 
entanglement of greed and grievance, of Hobbesian and Schmittian elements in small wars. Discussing "geography" in terms of terrain, location, concentration or commodity chains provides an account that (over-) emphasizes the greed dimension of small wars. It confines "geography" or "territory" to static conceptualizations, e.g. "locations" where violent events are recorded, resources are exploited or are traded. But beyond those patterns and phenomena, we find a lot else that is going on in small wars. Indeed, the "micro-foundations" are more complex than this type of literature has been willing to concede or to incorporate in their analytical framings. We find subaltern struggles for survival and subaltern opportunisms that link local livelihood struggles with war economies, greed with grievance. Small wars are about "rational madness" (Keen 1997) and the madness of rationality, affect and violence, everyday practices of resistance, complicity, coercion, consent, opportunism -all practices in the wake of "territorializing domination" (Mbembe 2001, 85).

Sketching the elements of an alternative research agenda has brought us back to Carl Schmitt and his - admittedly romanticizing - telluric characterization of the partisan who is, according to Schmitt, more than a pirate, more than a corsair, more than a criminal. Watts' analytics of governable spaces has pointed to the multiple mechanisms of territorialized rule and how identities and places are mobilized in political struggles during war by a multitude of actors (Ingram and Dodds 2009). It is the allusion to the "telluric" character of the partisan - telluric in the sense of relating to or inhabiting the land (as opposed to the sea or air) - and his (or her) struggle over meaning and belonging, which has informed the analytics of "geography of rule, violence and affect" - of the "telluric geographies" of small wars. The "telluric geographies" of small wars consist of the complex geography of actors, strategies, motivations and opportunities and of more than rational action and strategizing, all of 
which are territorialized. The partisan, writes Schmitt, is connected with the terrain and its population.

\section{REFERENCES}

Addison, T., Le Billon, P., Murshed, S.M. 2003: Conflict in Africa: The cost of peaceful behaviour. Journal of African Economies 11 (3): 365-86.

Agnew, J.A. 2009: Killing for Cause? Geographies of War and Peace. Annals of the Association of American Geographers 99 (5), 1054-1059.

Agnew, J.A. 1994: The territorial trap: The geographical assumptions of international relations theory. Review of International Political Economy 1 (1), 53-80.

Appadurai, A. 2007: Fear of Small Numbers: An Essay on the Geography of Anger. Durham: Duke University Press.

Auty, R. 2004: Natural resources and civil strife: a two-stage process. Geopolitics 9 (1), 29-49.

Auty, R. (ed.) 2001: Resource Abundance and Economic Development. Oxford: Oxford University Press.

Auty, R. 1995: The resource curse hypothesis. Economic Geography 71 (3), 257-272. Azam, J.-P. 2002: Looting and conflict between ethnoregional groups. Journal of Conflict Resolution 38, 429-444.

Azam, J.-P. and Hoeffler, A. 2002: Violence against civilians in civil wars: Looting or terror? Journal of Peace Research 39 (4), 461-485.

Ballentine, K., Sherman, J. 2003: The Political Economy of Armed Conflict: Beyond Greed and Grievance. Boulder CO, Lynne Rienner. 
Basedau, M. and Lay, J. 2009: Resource Curse or Rentier Peace? The Ambiguous Effects of Oil Wealth and Oil Dependence on Violent Conflict. Journal of Peace Research 46 (6), 757-776.

Bates, R., A. Greif and Singh. S. 2002: Organizing violence. Journal of Conflict Resolution 46, 599-628.

Beaumont, R. 1995. Small wars: Definitions and dimensions. The Annals of the American Academic of Political and Social Sciences 541, 20-35.

Bohle, H.-G. 2007: Geographies of violence and vulnerability. An actor-oriented analysis of the civil war in Sri Lanka. Erdkunde 61 (2), 129-146.

Bohle, H.-G. and Fünfgeld, H. 2007: The political ecology of violence in Eastern Sri Lanka. Development and Change 38 (4), 665-687.

Bøås, M. And K. Dunn 2007: African Guerrillas: Raging against the machine. Boulder CO: Lynne Rienner.

Boot, M. 2002: The Savage Wars of Peace: Small Wars and the Rise of American Power. New York: Basic Books.

Braithwaite, A. 2006: The geographic spread of militarized disputes. Journal of Peace Research 43 (5), 507-522.

Bridge, G. 2008: Global production networks and the extractive sector: governing resource-based development. Journal of Economic Geography 8, 389-419

Brosza, M. 2004: 'New wars' discourse in Germany. Journal of Peace Research 41 (1), 107-117.

Brunnschweiler, C. and Bulte, E.H. 2009: Natural resources and violent conflict: resource abundance, dependence, and the onset of civil wars. Oxford Economic Papers 61 (4): 651-674. 
Buhaug, H. 2007: The future is more than scale: a reply to Diehl and O'Lear. Geopolitics 12 (1), 192-199.

Buhaug, H., Gates, S. and Lujala, P. 2009: Geography, rebel capability, and the duration of civil conflict. Journal of Conflict Resolution 53 (4), 544-569.

Buhaug, H. and Gates, S. 2002: The geography of civil war. Journal of Peace Research 39 (4), 417-33.

Buhaug, H. and Lujala, P. 2005: Accounting for scale: Measuring geography in quantitative studies of civil war. Political Geography 24 (4), 399-418.

Buhaug, H. and Rød, J.K. 2006: Local determinants of African civil wars, 1970-2001. Political Geography 25 (3), 315-335.

Cederman, L.-E., Buhaug, H. and Rød, J.K. 2009: Etno-Nationalist dyads and civil war: a GIS-based analysis. Journal of Conflict Resolution 53 (4), 496-525.

Cederman, L.-E. and Gleditsch, K.S. 2009: Introduction to special issue on “Disaggregating Civil War”. Journal of Conflict Resolution 53 (4), 487-495.

Clapham, C. 1998: African Guerrillas. Oxford: James Currey.

Clausewitz, C. von 1966: Meine Vorlesungen über den kleinen Krieg, gehalten auf der Kriegs-Schule 1810 und 1811, in: Schriften, Aufsätze, Studien, Briefe, Vol. 1, edited by Werner Hahlweg, Göttingen, pp. 208-599.

Collier, P. 2000: Rebellion as quasi-criminal activity. Journal of Conflict Resolution $44(6), 839-853$.

Collier, P., Hoeffler, A. and D. Rohner 2009: Beyond greed and grievance: feasibility and civil war. Oxford Economic Papers 61 (2009), 1-27.

Collier, P. and Hoeffler, A. 2005: Resource rents, governance, and conflict. Journal of Conflict Resolution 49 (4), 625-633. 
Collier, P., Hoeffler, A. and Söderbom, M. 2004: On the duration of civil war. Journal of Peace Research 41 (3), 253-273.

Collier, P. and Hoeffler, A. 2004: Greed and grievance in civil war. Oxford Economic Papers 56, 563-595.

Collier, P. and Hoeffler, A. 2002: On the incidence of civil war in Africa. Journal of Conflict Resolution 46 (1), 13-28.

Collier, P. and Hoeffler, A. 1998: On the economic causes of civil war. Oxford Economic Papers 50, 563-73.

Collinson S. 2003: Power, Livelihoods and Conflict - Case Studies in Political Economy Analysis of Humanitarian Action. HPG Report 13, London: Overseas Development Institute (ODI).

Cooper, N. 2002: State collapse as business: The role of conflict trade and the emerging control agenda. Development and Change 33 (5), 21-38.

Cramer, C. 2006: Civil War is not a Stupid Thing. Accounting for Violence in Developing Countries. London: Hurst.

Cramer, C. 2002: Homo economicus goes to war: Methodological individualism, rational choice and the political economy of war. World Development 30 (11), 18451864.

Daase, C. 1998: Kleine Kriege, grosse Wirkung. Baden-Baden: Nomos.

Dalby, S. 2004: Ecological politics, violence and the theme of empire. Environmental Politics 4 (2), 1-11.

Dalby, S. 2007: Geopolitical knowledge: Scale, method and the "Willie Sutton Syndrome”. Geopolitics 12 (1), 183-191.

Daniel, V. (1996) Charred Lullabies: Chapters in an Anthropography of Violence. Princeton NJ: Princeton University Press. 
Das, V., Kleinman, A. and M. Ramphele (2000) Violence and subjectivity. Berkeley CA: University of California Press.

DeRouen, K.R. and Sobek, D. 2004: The dynamics of civil war duration and outcome. Journal of Peace Research 41, 305-20.

De Soysa, I. 2002: Paradise is a bazaar? Greed, creed and governance in civil war, 1989-99. Journal of Peace Research 39 (4), 395-416.

De Soysa, I. and Neumayer, E. 2007: Resource wealth and the risk of civil war onset: Results from a new dataset of natural resource rents, 1970-1999. Conflict Management and Peace Science 24 (3), 201-218.

Dixon, J. 2009: What Causes Civil Wars? Integrating quantitative research findings. Review of International Studies 11, 707-735.

Dunning, T. 2005: Resource dependence, economic performance, and political stability. Journal of Conflict Resolution 49 (4), 451-482.

Elwert, G. 1999: Markets of Violence. In: Elwert,G., Feuchtwang, S. and Neubert, D., editors, Dynamics of Violence. Processes of Escalation and De-escalation in Violent Group Conflicts, Berlin: Duncker \& Humblot, 85-102.

Elwert, G. 1997: Gewaltmärkte. In: von Trotha, T., editor, Soziologie der Gewalt. Opladen: Westdeutscher Verlag, 86-101.

Englebert, P. and Ron, J. 2004: Primary commodities and war: Congo-Brazzaville's ambivalent resource curse. Comparative Politics 37 (1), 61-81.

Enzensberger H.M. 2006: Schreckens Männer: Versuch über den radikalen Verlierer. Frankfurt a.M.: Suhrkamp.

Fearon, D. 2005: Primary commodity exports and civil war. Journal of Conflict Resolution 49 (4), 483-507. 
Fearon, D. 2004: Why Do Some Civil Wars Last So Much Longer Than Others? Journal of Peace Research 41(3): 275-301.

Fearon, J.D. and Laitin, D. 2003: Ethnicity, insurgency and civil war. American Political Science Review 97(1), 75-90.

Feldman, A. (1997) Violence and Vision: The prosthetics and aesthetics of terror. Public Culture 10 (1), 24-60.

Fjelde, H. 2009: Buying peace? Oil wealth, corruption and civil war, 1985-99. Journal of Peace Research 46 (2), 199-218.

Flint, C., editor, 2005: The geography of war and peace: From death-camps to diplomats. Oxford: Oxford University Press.

Fünfgeld, H. 2007: Fishing in Muddy Waters: Socio-environmental Relations under the Impact of Violence. Saarbrücken: Breitenbach Verlag.

Gaasbeek, T. 2010: Bridging troubled waters? Everyday inter-ethnic interaction in a context of violent conflict in Kottiyar Pattu, Trincomalee, Sri Lanka. PhD

Dissertation, University of Wageningen, NL.

Gates, S. 2002: Recruitment and allegiance: The microfoundations of rebellion. Journal of Conflict Resolution 46, 111-130.

Ginty, R.M. 2004: Looting in the contest of violent conflict: a conceptualization and typology. Third World Quarterly 25, 857-870.

Goodhand, J. 2003: Enduring disorder and persistent poverty: a review of linkages between war and chronic poverty. World Development 31 (3), 629-646.

Goodhand, J., Hulme, D. and Lewer N. 2000: Social capital and the political economy of violence: A case study of Sri Lanka. Disasters 24 (4), 390-406.

Gregory, D. 2010: War and peace. Transactions of the Institute of British Geographers NS 35, 154-186. 
Gregory, D. and Pred, A., editors, 2007: Violent geographies. London, New York: Routledge.

Hedges, C. 2002: War Is a Force that Gives Us Meaning. New York: Anchor. Hegre, H., Østby, G. And C. Raleigh, 2009: Poverty and Civil War Events: A Disaggregated Study of Liberia. Journal of Conflict Resolution 53(4): 598-623. Homer-Dixon, T. 1999: Environment, Scarcity and Violence. Princeton NJ: Princeton University Press.

Humphreys, M. 2005: Natural resources, conflict, and conflict resolution: uncovering the mechanisms. Journal of Conflict Resolution 49 (4), 508-537.

Ingram, A., Dodds, K. 2009: Spaces of Security and Insecurity: Geographies of the War on Terror. Aldershot: Ashgate.

Jean, F. and Rufin, J.-C., editors, 1996: Economies des Guerres Civiles. Paris: Hachette.

Jünger, E. 2010: Kriegstagebuch 1914-18. [Edited by Helmuth Kiesel]. Stuttgart: Klett-Cotta.

Kaldor, M. 1999: New and Old Wars. Organized violence in a global era. Cambridge: Polity Press.

Kalyvas, S. 2008: Promises and Pitfalls of an Emerging Research Program: The micro-foundations of civil war. In: S. Kalyvas, I. Shapiro and T. Masoud, editors, Order Violence and Conflict. New York: Cambridge University Press, 397-421. Kalyvas, S. 2006: The Logic of Violence in Civil War. Cambridge: Cambridge University Press.

Kalyvas, S. 2003: The Ontology of "Political Violence": Action and identity in civil wars. Perspectives in Politics 1 (3), 475-494. 
Kalyvas, S. 2001: 'New' and 'old' civil wars: a valid distinction? World Politics 4 (1), pp. 99-118.

Kalyvas, S., Kocher, M.A. 2009: The Dynamics of Violence in Vietnam: An analysis of the Hamlet Evaluation System (HES). Journal of Peace Research 46 (3), 335-355. Karl, T. 1997: The Paradox of Plenty: Oil Booms and Petro-States. Berkeley: University of California Press.

Keen, D. 2008: Complex Emergencies. London: Polity.

Keen, D. 2005: Conflict and Collusion. Oxford: James Currey.

Keen, D. 2000: War and peace: What's the difference? International Peacekeeping 7 (4), $1-22$.

Keen, D. 1998: The economic functions of violence in civil war. Adelphi Paper 320, London: International Institute of Strategic Studies.

Keen, D. 1997: A rational kind of madness. Oxford Development Studies 25, 67-75. Kobayashi, A. 2009: Geographies of peace and armed conflict: Introduction. Annals of the Association of American Geographers 99 (5), 819-826.

Korf, B. 2004: War, livelihoods and vulnerability in Sri Lanka. Development and Change 35(2): 275-295.

Korf, B. 2005: Rethinking the greed-grievance nexus: property rights and the political economy of war in Sri Lanka. Journal of Peace Research 42(2): 201-217.

Korf, B. 2006: Cargo Cult Science, Armchair Empiricism and the Idea of Violent Conflict. Third World Quarterly 27 (3), 459-476.

Korf, B., Engeler, M. and Hagmann, T. 2010: The geography of warscape. Third World Quarterly 30 (3), 385-399.

Korf, B. and Engeler, M. 2007: Geographien der Gewalt. Zeitschrift für Wirtschaftsgeographie $51(3+4), 221-237$. 
Korf, B. and Fünfgeld, H. 2006: War and the commons: assessing the changing politics of violence, access and entitlements in Sri Lanka. Geoforum 37 (3): 391-403. Kurtenbach, S. und Lock, P. 2004: Kriege als (Über)Lebenswelten.

Schattenglobalisierung, Kriegsökonomien und Inseln der Zivilität. Bonn: Dietz.

Le Billon, P. 2008: Diamond Wars? Conflict Diamonds and Geographies of Resource Wars. Annals of the Association of American Geographers, 98 (2), 345-372.

Le Billon, P. 2007: Scales, Chains and Commodities: Mapping Out 'Resource Wars'. Geopolitics 12 (1), 200-205.

Le Billon, P. 2006: Fatal transactions: Conflict diamonds and the (anti)terrorist consumer. Antipode 38 (4), 778-801.

Le Billon, P. 2005a: The geopolitics of 'resource wars': Resource dependence, governance and violence. London: Routledge.

Le Billon, P. 2005b: The geography of "resource wars”. In: Flint, C., editor, 2005: The geography of war and peace: From death-camps to diplomats. Oxford: Oxford University Press, 217-241.

Le Billon, P. 2004: The geopolitical economy of 'resource wars'. Geopolitics 9 (1), 128.

Le Billon, P. 2001: The political ecology of war. Political Geography 20 (5), 561-84. Lubkemann, S. 2007: Culture in Chaos: An Anthropology of the Social Condition in War. Chicago: Chicago University Press.

Lujala, P. 2010: The spoils of nature: Armed civil conflict and rebel access to natural resources. Journal of Peace Research 47 (1), 15-28.

Lujala, P. 2009: Deadly combat over natural resources: Gems, Petroleum, drugs, and the severity of armed civil conflict. Journal of Conflict Resolution 53 (1), 50-71. 
Lujala, P., Gleditsch, N.P. and Gilmore, E. 2005: A diamond curse? Civil war and lootable resource. Journal of Conflict Resolution 49, 538-62.

Lunstrum, E. 2009: Terror, territory and deterritorialization: Landscapes of terror and the unmaking of state power in the Mozambican 'civil' war. Annals of the Association of American Geographers 99 (5), 884-892.

Macamo, E. 2006: Accounting for disaster: memories of war in Mozambique. Afrika Spektrum 41 (2), 199-219.

Mack, A. 2002: Civil war: academic research and the policy community. Journal of Peace Research 39, 515-25.

Maconachie, R. and Binns, T. 2007: Beyond the resource curse? Diamond mining, development and post-conflict reconstruction in Sierra Leone. Resource Policy 32 (3), 104-115.

Mbembe, A. 2001: On the Postcolony. Berkeley CA: University of California Press. Mehler, A. 2004: Oligopolies of violence in Africa south of the Sahara. Nord-Süd aktuell 3, 539-548.

Mehlum, H., Moene, K. and Torvik, R. 2006: Institutions and the resource curse. The Economic Journal 116 (508): 1-20.

Mehlum, H., Moene, K. and Torvik, R. 2002: Plunder and protection Inc. Journal of Peace Research 39, 447-459.

Meyer, R., Schetter, C. and J. Prinz (2010) Spatial Contestations? The Forgotten Theological-Political Trajectory of Carl Schmitt. [Unpublished paper].

Münkler, H. (2002) Die neuen Kriege. München: C.H. Beck.

Murshed, S.M. and Tadjoeddin, M.Z. 2009: Revisiting the greed and grievance explanations for violent internal conflict. Journal of International Development 21, 87-111. 
Murshed, S.M. and Gates, S. 2005: Spatial-Horizontal Inequality and the Maoist Insurgency in Nepal. Review of Development Economics 95, 796-816.

Nordstrom, C. 2004: Shadows of War: Violence, Power, and International

Profiteering in the Twenty-First Century, Berkeley, University of California Press.

O’Lear, S. and Diehl, P.F. 2007: Not drawn to scale: Research on Resource and

Environmental Conflict. Geopolitics 12 (1), 166-182.

O'Loughlin, J. 2005: The political geography of conflict: civil wars in the hegemonic shadow. In: Flint, C., editor, 2005: The geography of war and peace: From deathcamps to diplomats. Oxford: Oxford University Press, 85-112.

O'Loughlin, J., Witmer, F., Linke, A. 2010: The Afghanistan-Pakistan Wars, 20082009: Micro-geographies, conflict diffusion, and clusters of violence. Eurasian Geography and Economics 51 (4), 437-471.

O'Loughlin, J. and Witmer, F. 2010: The localized geographies of violence in the North Caucasus of Russia 1999-2007. Annals of the Association of American Geographers, forthcoming [page numbering follow pre-pring pdf downloaded from: http://www.colorado.edu/ibs/PEC/johno/pubs.html].

O’Loughlin, J. and Raleigh, C. 2007: Spatial analysis of civil war violence. In: K. Cox, Low, M. and Robinson, J., editors, Handbook of Political Geography. Thousand Oaks, CA: Sage.

Olson, WM. J. 1995. Preface: Small wars reconsidered. The Annals of the American Academy of Political and Social Science, 541, 8-19.

Olson, M. 2000: Power and Prosperity: outgrowing communist and capitalist dictatorships. New York: Basic Books.

Olsson, O. 2006: Diamonds are a rebel's best friend. World Economy 29 (8), 1133 1150. 
Ossenbrügge, J. 2007: Ressourcenkonflikte ohne Ende? Zur Politischen Ökonomie afrikanischer Gewaltökonomien. Zeitschrift für Wirtschaftsgeographie 51 (3+4), 150162.

Raleigh, C., Witmer, F. and O'Loughlin, J. forthcoming: A review and assessment of spatial analysis and conflict: The geography of war. In: Flint, C., editor, Geographic Contributions to International Studies. Oxford: Blackwell.

Raleigh, C. and H. Hegre 2009: Population size, concentration, and civil war. A geographically disaggregrated study. Political Geography 28, 224-238.

Raleigh, C., Hegre, H. and Carlson, J. 2009: Introducing ACLED: An armed conflict location and event dataset. Typescript. PRIO, Oslo.

Reno, W. 1999: Warlord Politics and African States. Boulder CO: Lynne Riener. Richards, P. 2005: No Peace, No War: An Anthropology of Contemporary Armed Conflicts. Athens: Ohio University Press.

Richards, P. 1996: Fighting for the Rain Forest: War, Youth and Resources in Sierra Leone. Oxford: James Currey Publishers.

Ron, J. 2005: Paradigm in distress? Primary commodities and civil war. Journal of Conflict Resolution 49 (4), 443-450.

Ross, M. 2006: A closer look at oil, diamonds, and civil war. Annual Review of Political Science 9, 265-300.

Ross, M. 2004: What do we know about natural resources and armed conflict. Journal of Conflict Resolution 41 (3), 337-356.

Ross, M. 1999: The political economy of the resource curse. World Politics 51 (2), 297-322. 
Rustad, S.C.A., Rod, J.K., Larsen, W. and Gleditsch, N.P. 2008: Foliage and fighting:

Forest resources and the onset, duration, and location of civil war. Political

Geography 27 (7), 761-782.

Sachs; J. and Warner, A.2001: The curse of natural resources. European Economic Review 45 (4-6), 827-38.

Sachs, J.D. and Warner, A.M 1995: Natural Resource Abundance and Economic Growth, NBER Working Paper no. 5398.

Said, E. 1993: Culture and Imperialism. London: Vintage.

Scheper-Hughes, N. and P. Bourgeois (2004) Violence in War and Peace: An Anthology. Malden MA, Oxford: Blackwell.

Schlichte, K. 2009: In the Shadow of Violence: The Politics of Armed Groups, Chicago: Chicago University Press.

Schlichte, K. 2007: Die politische Ökonomie des Krieges. Berliner Debatte Initial 18 (6), $72-84$.

Schmitt, C., 1996: Der Begriff des Politischen. Text von 1932 mit einem Vorwort und drei Corollarien. Berlin, Duncker \& Humblot [1932].

Schmitt, Carl 2006: Theorie des Partisanen. Zwischenbemerkung zum Begriff des Politischen. Berlin: Duncker \& Humblot [1963].

Scott, J. 1985: Weapons of the Weak: Everyday Forms of Peasant Resistance. New Haven: Yale University Press.

Skaperdas, S. 2007: An economic approach to analyzing civil wars. University of California-Irvine, Department of Economics, Working Papers series, No. 060715. Skaperdas S. 2002: Warlord competition. Journal of Peace Research 39(4): 435-446. Sloterdijk, P. 2006: Zorn und Zeit. Frankfurt a.M.: Suhrkamp. 
Snyder, R. and Bhavnani, R. 2005: Diamonds, blood, and taxes: A revenue-centered framework for explaining political order. Journal of Conflict Resolution 49 (4), 563 597.

Snyder, R. 2006: Does lootable wealth breed disorder? A political economy of extraction framework. Comparative Political Studies 39 (8), 943-968.

Sofsky, W. 2003: Violence: Terrorism, Genocide, War. London: Granta Books. Spencer, J. 2007: Anthropology, Politics, and the State: Democracy and Violence in South Asia. Cambridge, New York: Cambridge University Press.

Straus, S. 2006: The Order of Genocide: Race, Power, and War in Rwanda. Ithaca, NY: Cornell University Press.

Tarrow, S. 2007: Inside Insurgency: Politics and violence in an age of civil war. Perspectives in Politics 5 (3), 587-600.

Thies, C.G. 2010: Of Rulers, Rebels and Revenue: State capacity, civil war onset, and primary commodities. Journal of Peace Research 47 (3), 321-332.

Thrift, N. 2007: Immaculate warfare? The spatial politics of extreme violence. In:

Gregory, D. and Pred, A., editors, Violent geographies. London, New York: Routledge, 273-294.

Utas, M. 2005: Victimcy, girlfriending, soldiering. Tactic agency in a young woman's social navigation of the Liberian war zone. Anthropological Quarterly, 78 (2), 2005, 403-430.

Verwimp, P. 2006: Machetes and Firearms: The organization of massacres in Rwanda. Journal of Peace Research 43 (1), 5-22.

Verwimp, P., Justino, P., Brück, T. 2009: The Analysis of Conflict: A micro-level perspective. Journal of Peace Research 46 (3), 307-314. 
Vigh, H. 2006: Navigating Terrains of War: Youth and Soldering in Guinea-Bissau, Oxford, New York: Berghahn Books.

Watts, M. 2000: Struggles over geography: Violence, freedom and development at the millennium. Hettner-Lectures 1999, Heidelberg: University of Heidelberg.

Watts, M. 2003: Development and governmentality. Singapore Journal of Tropical Geography 24 (1), 6-34.

Watts, M. 2004a: Antinomies of community: some thoughts on geography, resources and empire. Transactions of the Institute of British Geographers 29 (2), 195-216.

Watts, M. 2004b: Resource curse? Governmentality, oil and power in the Niger Delta, Nigeria. Geopolitics, 9 (1), 50-80.

Weidmann, N.B. 2009: Geography as motivation and opportunity: Group concentration and ethnic conflict. Journal of Conflict Resolution 53 (4), 526-543. Weidmann, N.B., Rød, J.K., L.-E. Cederman 2010: Representing ethnic groups in space: A new dataset. Journal of Peace Research 47 (4), 491-499.

Weinstein, J.M. 2007: Inside Rebellion: The Politics of Insurgent Violence. Cambridge: Cambridge University Press.

Welsch, H. 2008: Resource abundance and internal armed conflict: Types of natural resources and the incidence of 'new wars'. Ecological Economics 67 (3), 503-513. Wrigley, N. and Overman, H. 2010: Editorial: The $10^{\text {th }}$ year of the Journal of Economic Geography: a decade of high impact publication. Journal of Economic Geography 10 (1), 1-8. 